\title{
The effect of vitamin c supplementation on intercellular adhesion molecule-1 (ICAM-1) concentration on male adolescent obesity in Padang
}

\author{
Hernofialdi, Eka Agustia Rini, Rizanda Machmud
}

From 7th APPES Biennial Scientific Meeting

Nusa Dua, Bali. 14-17 November 2012

\section{Background}

The role of Vitamin $C$ as antioxidant has been known. Obesity is an oxidative stress condition which becomes risk factor of cardiovascular disease, which could be detected through ICAM-1 concentration.

\section{Objective}

To examine the effect of Vitamin $\mathrm{C}$ supplementation on the ICAM-1 concentration on male adolescent obesity in Padang.

\section{Method}

The randomized double blind controlled trial of 40 obese adolescent boys aged 14-18 years old were performed on March-May 2011. Subjects were classified into 2 groups, the Vitamin C $500 \mathrm{mg}$ treatment group and the control group which got placebo, twice daily for 8 weeks. The ICAM-1 concentration of both groups was examined before and after the treatment. The data were analyzed with paired sample t-test and independant $\mathrm{t}$-test with significant degree $\mathrm{p}<0.05$.

\section{Result}

The mean of initial ICAM-1 concentration in Vitamin C and placebo group were 370.37 (SD155.09) $\mathrm{ng} / \mathrm{ml}$ and 232.96 (SD 106.48) ng/ml, respectively. After 8 weeks treatment, the mean of ICAM-1 concentration on the vita$\mathrm{min} \mathrm{C}$ and placebo group were 183.32 (SD 52.34) $\mathrm{ng} / \mathrm{ml}$ and 185.06 (SD 52.34) ng/ml; the mean of ICAM-1 concentration decreased in both group with p 0.007 and

Endocrinology Division, Pediatric Health Departement of Medical Faculty Andalas University, Dr. M. Djamil Hospital Padang
$<0.05$, concecutively. The reducing Delta of ICAM- 1 concentration in vitamin $C$ and placebo group were 187.04 (SD 131.5) $\mathrm{ng} / \mathrm{ml}$ and 47.91 (SD 62.25) $\mathrm{ng} / \mathrm{ml}$, respectively. The reducing Delta of ICAM-1 concentration in Vitamin $C$ group were higher than placebo group, with ratio $3.9: 1$ $(\mathrm{p}<0.05)$.

\section{Conclusion}

Vitamin $C$ supplementation in obese adolescent boys reduce the ICAM-1 concentration.

Published: 3 October 2013

doi:10.1186/1687-9856-2013-S1-P86

Cite this article as: Hernofialdi et al: The effect of vitamin c

supplementation on intercellular adhesion molecule-1 (ICAM-1)

concentration on male adolescent obesity in Padang. International

Journal of Pediatric Endocrinology 2013 2013(Suppl 1):P86.

Submit your next manuscript to BioMed Central and take full advantage of:

- Convenient online submission

- Thorough peer review

- No space constraints or color figure charges

- Immediate publication on acceptance

- Inclusion in PubMed, CAS, Scopus and Google Scholar

- Research which is freely available for redistribution

Submit your manuscript at www.biomedcentral.com/submit C Biomed Central 